\title{
Dream and Interpretation A Point View in Governmental Strategic Financial Planning Derived from Islamic Religion
}

\author{
Dr KHALED JAMAL JAARAT \\ Associate Professor, Department of Accounting, Middle East University \\ Email: khaledjaarat@yahoo.com
}

\begin{abstract}
In this study, the researcher investigated how to finance deficit of budget without borrowing or asking others to help out, that method derived from Islamic religion through discussing the ideas mentioned in verses 47-49 from Yusuf Surah, Those verses relate to the interpretation of the dream of the king that interpreted by prophet Yusuf peace upon him, the dream mentioned in verse 43. Researcher discussed the budgeting process, the approaches of preparing budgets, and criticisms of the current approaches of preparing budgets. The researcher concluded that the methods of preparing budgets are insufficient to achieve efficiency and effectiveness of good financial planning and financial control, since the budgets in most countries suffered from deficits, suggested an Islamic approach, benefit from the basics of preparing budget, morals, ethics, and values mentioned in Yusuf Surah, that it must be followed by those who treat with public funds.
\end{abstract}

Keywords: Dream, Interpretation, Budgeting, Deficit, Surplus, Financing.

\section{Introduction}

Day after day, the importance of financial planning increased especially for governments, because of the limited resources and funds in the country, beside the main attribute of current budgets in most countries, that is annual expenditures exceed annual revenues which resulted in absolute deficit, all of the available solutions are failure in minimize or delete deficits, because of that, researcher look for solution to deficit in Islamic religion since there are a dimensions relate to financial planning not mentioned in legislations, that are controls to be faith, fair, truth, trustworthy, workaholic, well doing and loyal official, beside believe in Allah and the latest day for the purposes of accountability.

In this field, the researcher discussed the dimensions in Islamic religion of strategic governmental financial planning, in detailed reading to budgets of most countries now a days suffered from deficits, and day after day, the amounts of deficits increase and reach to non reasonable levels, that obliged governments to look for methods for financing deficits, some times by borrowings, whether from local institutions or through issuing treasury bonds in the local market, or by external borrowing through issuing treasury bonds in the international market or from the world bank, the latter one impose very difficult conditions in order to release loans, some of these conditions affect independency of political lordship and its decisions, other times require internal procedures must be adopted by governments like financial polices especially those relate to taxes, financial support to specific goods, or depending on foreign aids that also attribute to difficult conditions, and the like. 
Question to be raised here: are these methods are the only methods to finance deficit of the budget? The answer is: no, there are several methods to finance deficit of budget other than the traditional methods by borrowing, but need a strong-willed procedures, decisions, restructurings, and so on.

The idea of the study that lead to the title of it is the dream of a former king in Egypt, and its interpretation by prophet Yousif peace of Allah upon him, that evade people of Egypt that days from starvation, researcher will benefit from the interpretation to treat with deficits of budgets.

\section{Problem of the study}

The deficits of budgets are a absolute fact for most budgets of governments, that lead to several methods to finance deficits burden the economics, accompany by hard procedures adopted by governments, foreign debts and impose taxes are the main methods to finance the deficits.

But the previous methods are not the only methods to finance deficits, since there are preferable methods may achieve better financial planning resulted in minimization of deficits and deletion it progressively. The researcher will propose an integrated approach in preparing budgets derived from Islamic religion, depending on versus(Ayat) 47 to 49 in Yousif Sura in Quarn.

According to for mentioned, the main question of the study can be formulated as follow:

1. How the governments prepares its budgets?

2. What are the criticisms to entire process of budgeting?

3. What are the principles in Islamic religion in budgeting?

4. Is it possible to set an integrated proposal for budgeting derived from Islamic religion?

\section{Method of the Study}

Researcher will adopt the exploratory method through discussing the controls and procedures of budgeting mentioned in Islamic religion, in order to possible setting an integrated proposal in budgeting.

\section{Literature Review}

Budget can be defined as a future plan for the coming year includes estimation for revenues and expenditures, or estimated statement to governmental expenditures and revenues during future period of time to control revenues and expenditures

Budget as a plan can be used as a tool of control, it is considered as double coin faces, the first face relates to planning, while the second face relates to control.

Governments adopt several methods of budgeting, there are five methods as follow:

1. Line Item Budgeting (LIN): it represents the oldest method of budgeting, called control budget or traditional budget, expenditures presented as items according to its objective for every governmental unit, while revenues presented according to its source, many advantages to LIN approach such as: simplicity of preparation, minor arithmetic calculations, understandability, and adoption of negotiations between governmental departments and department of budget. Criticisms and disadvantages of it are LIN focuses on how to earn revenues regardless of its efficiency and performance effectiveness, ignorant of public financial policies, ignorant of priorities of programs, and random estimation to amounts of items included in budget.

2. Programs and Performance Budgeting (PPB): budget in which governmental operations translated into applicable programs and plans, at the same time, performance measurement keys used 
to recognize to what extent planned programs fulfilled, its presentations, basically separate governmental operations from non governmental, it adopts functional classification, and dividing functions to programs, programs to activities, and identifying cast elements for every activity, many advantages to PPB such as: estimations carried out according to accurate scientific basics, adoption of materiality to activities, enlarge authorities of managers in planning and control, and finally translation of public policies into programs, while disadvantages and criticisms of PPB such as: the need for qualified human resources to adopt it, interrelationships between activities, programs and classification according to LIN, the need for political well for applying it, and finally the need for amending regulations and laws relate to activities, programs.

3. Planning, Programming Budgeting System (PPBS): budget that translates long and medium governmental objectives and policies to annual functions and programs, it uses quantitative methods to compare between objectives and policies and allocation of financial funds, its presentation depends on identifying the structural dimensions: functions, programs, and cost elements as in PPB, then identifying analytical dimensions according to three levels: first level relates to planning, second level relates to programming, and the third level relates to budgeting, finally identifying information dimensions. Many advantages to PPBS such as: focusing on identifying main objectives to government, PPBS take on consideration the available resources, and focusing on available alternatives to achieve objectives and choose the best one, while disadvantages and criticisms of PPBS such as: difficulty of formulating the objectives and resulted problems accurately and comprehensively, difficulty of choosing measurements of performance especially in service departments, difficulty in analyzing cost and benefit, and focusing on centrality of decision.

4. Zero-Based Budgeting (ZBB):budget depends on zero basis in expenditures annually, that means budget starts with identifying new activities and programs, then allocation of budget according to results of valuation. Many advantages to $\mathrm{ZBB}$ such as: it is suitable to multiple and different needs governmental departments, estimation of expenditures carried out accurately and connected to strategic objectives of government, finally it depends on management by objectives (MBO), while disadvantages and criticisms of PPBS such as: it depends on delegation of authority, governmental departments and ministries focusing on routine operations, the need for accurate and clear measurements keys, weakness of self assessment, and absence of code of conduct.

5. Contractual budget: budget is a system for transactions' contracts between central government and executive parties, many advantages to contractual budget such as: performing basic solutions to problems in governmental departments, connection of budget to development plans, and executions of governmental programs and projects effectively and economically. While its disadvantage are not appeared since this method is modernistic one.

\section{Criticisms to Entire Process of Budgeting}

Before discussing the proposed method of budgeting derived from Islamic religion, researcher will discuss the criticisms of the entire process of budgeting in the following part of the study, whether relate to the budgeting approaches, or to the policies of financial planning and budgeting, those criticisms may be as follows:

1. The current approaches focus on future estimation of expenditure and forecasting revenues to specific coming year, without paying any attention to possibility of multi-year budgets that exceed year basis, this can be resulted in the following disadvantages:

a. Ignoring long term visions and strategies that assumed to be achieved through a period exceed one year, accordingly, excluding these missions and strategies clearly and transparently from considering it in budgets because of its absolute impact on these budgets, that indicate to the intention of governments not to reach with the balance of debts to zero, and only take in consideration the matured payments and interest payable in the current budget. 
b. Ignoring the development plans and other plans that its periods exceed next year, such as fifth or seventh plans, because absence of long term financial planning, budgets only include expenditures of these plan relate only to the next year.

c. The difficulty to deal with crises that take more than one year, resulted in ignoring negative impact of it, that can be indicated by no budgets cover crises period.

2. The current approaches focus on future estimation of expenditure and forecasting revenues to specific future year, without paying any attention to possibility of breaking down the annual budgets to interim budgets on the bases of semi, quarterly, that resulted in absence of continuous controls and revisions to the estimations included in budgets till the end of the year while preparing the closing accounts .

3. Considering governmental capital expenditures as expenses relate to the period according to governmental accounting policies, since applying cash basis in accounting, in light of absence of accurate statistical books, this criticisms resulted in the following disadvantages:

a. The weakness of control process, that lead to waste invested resources in the form of assets.

b. Ignorant of applying generally accepted accounting policies that look to the capital expenditures as assets, accordingly, cause what may be called assets erosion, this problem can be solved by applying International Public Sector Accounting Standards(IPSAS) that depend on accrual basis.

c. The difficulties of achieving expected benefits behind budgets as a financial plans aim to achieve control on expenditures, since assets considered as expenditures.

d. The absence of replacement plans to assets according to its productive lives and its situations, in spite of governments practices in reality with private sector to determine limits to the depreciation averages in terms of taxes reports, but the depreciation concept not applied in governmental sector to the same categories of assets.

4. Budgets approaches do not include the classification of expenditures according to economic fields such as agriculture water, development, sustainability, and the like, that criticism resulted in the following disadvantages:

a. Ignoring the ladder of essential needs, the core one is maintaining human being from starving because of the minority of food, or thirsty because of the minority of water.

b. The most centralized fields of expenditures are the military and security fields through arming, training, qualifying ..etc, in spite of absence of clear future visions relate to global security, what makes it worst centralizing on internal security so as to protect political regimes and rule over nations when asking their rights.

c. The absence of considering agriculture as a basic activity and field in providing strategic goods like wheat, since it is the most important good for every society, because it represents the main food for human being, and its remnants used as the main food for animals that constitute the food for human being.

d. Avoid focusing on capital expenditure that resulted in increase gross domestic production, such as agricultural investment expenditure or irrigation investment expenditure, while focusing on unproductive expenditure like infrastructure, buildings, and plants that do not contribute in increase gross domestic production.

e. There is no protection to public funds and revenues, however, the public fund considered as the weakness point that lead to ignore maintaining it, whether in investing, collecting, or disbursing it, that can be noticed through quick richness to persons whom assigned in governments, the related problem to this situation is the weakness control on public fund, since most of rubbery, bribery, and other bad practices cases end with vindication to its perpetrator.

f. Also, there is no attention paid to achieving social justice, especially that relate to wages, salaries and other incentives paid to public employees, such as the cases of more one salaries ladder in the country, whether to working or the retired employees. 
5. Governments while conducting financial planning and preparation of budgets responsible for paying attention to strategic goods in country, but all of the budgeting approaches in order to maintain the minimum limit of balances of those goods, this may result in the following disadvantages:

a. There is no control on storing, in and out transactions of these goods, that lead to maintain the strategic balance of it, and planning to finance it, the issue leaved to greediness of private sector, that result in monopoly of importing these goods under the protection of law in different names like: intellectual property, agencies, franchises and so on, beside quick illegal richness at the expense of poorness people, and redistribution of income and wealth to the interest of rich people, beside increase in financial and administrative corruption.

b. The worst choosing of controllers and employees with poor ethics, morals, and practical or/and theoretical expertise.

6. Also, all budgeting approaches depend basically on estimation of expenditures as a starting point in preparation of budget, after that determining how to finance these expenditures, that resulted in the following disadvantages:

a. No attention paid to estimation of expenditures in light of available financial resources, that resulted in high probable of deficit, since there is no consideration to limited resources in order to estimate expenditures in light of it.

b. The absolute result to what mentioned in (a) above is the efforts done by the governments to look for sources of financing deficit, whether through external sources such as borrowing, or internal sources such as increasing rates of taxes and fees .

c. In order to finance the deficit, governments borrow from international financers like international bank in a very hard terms and conditions reached to sovereign of it, with a high interests borrowing cost, at the same time these loans resulted in unfair and injustice to the low income people, because it leads to increase prices especially to basic goods like rice, bread, sugar, and so on, in order to pay the dept service, also decrease the claimed social security support, or impose new taxes.

d. The absence of systematic thinking by the planners and those responsible for applying budgets and plans, that relate to fulfillment of needs according to its priorities in consideration of available resources, which lead to a gap between how to manage private properties and public properties, if public employees and other related parties treat the public funds like the private funds, really that pratice resulted in maintaining the public funds from oppressive, unworthy, and wrongful use.

7. Because of the plurality of needs that expenditures estimation depends on, most of time governments do not consider the priority of these needs, the first priority must go to the food of nations to maintain humanity, and differ it from the unnecessary needs, for example governments intend to include budgets with funds to build bridges, roads, buildings, and arming, at the same minimize the essential support to basic needs for human being like food, and feed of animals, and while its nations suffered from starving, all the budgeting approaches support the less priority needs like expenditures on public security, and in some countries budgets include expenditures on supporting tobacco plant instead of wheat.

8. Governments pay less attention to orientation of resources to the activities and fields that achieve a high return, for example ignoring planning to agriculture and water through less support to it in different approaches of budgeting to maintain the basics necessary to sustainability development of it, in addition to that, governments through budgets do not make comparisons between usages of resources in order to allocate it to the best use from the point view of society, and not concentrate only on cash return.

9. There is no connection between budget and the top authority in country except in approving it, that lead to the following disadvantages:

a. The absence of continuous following to the expenditures especially for the capital class, that result in most times in destruction to the related projects. 
b. Looking to budget as a mean of determining the ceiling of expenditures and the floor of revenues, without any efforts of commitment to make budget an effective tool of controlling revenues and rationalizing the expenditures which lead to bad practices and treatments with public funds and resources, these practices result in wasting resources that supposed to be the main aim of the budgets since budget concerns with planning the financial needs and how to fulfill it through limited resources.

10. The approaches of budgeting ignore adoption of risk-based financial budgeting, that resulted in reduce flexibility in budgets during crises, the disadvantages of that are:

a. Ignoring of crises take place, that obliged governments to treat crises through issuing budgets annexes and other exceptional procedures in order to secure the financial funds necessary for these crises.

b. There are no alternative plans and budgets to treat with crises and other incidental situations, instead of that, governments focus on one budget, and making exceptions to it, that resulted in treat process of financial budgeting and planning disrespectfully.

11. Nowadays, budgets discussed for the purposes of proving it by parliament, this procedure can be criticized that members of parliaments in most countries are not qualified and have not any expertise in budget and related matters, that lead to weak discussions and comments, they look to it as routine stage in approving budget, also, it supposed that those parliament members have to be empowered to approve or reject budget, in most countries especially less developed, parliament members can not discuss the unity and comprehensiveness of budgets, however the governments justify that by maintaining the sensitivity and mastery of some departments, the non discussed budgets to those departments some times constitute the majority of budget, or hidden budgets may be double the declared one. This criticism resulted in the following disadvantages:

a. Absence of control and accountability the expenditures of those departments, with high probable of wasting public expenditures.

b. The obstruction of budget unity, since there are declared and hidden budgets.

\section{Islamic Principles of Preparation of Budget}

Before discussing the proposed approach of budgeting, researcher will discuss firstly the Islamic principles of preparation the budgets that are as follow:

1. Believe in Allah, generate commitment to do the best things that Allah orders to do it, and avoid the bad things that Allah forbade it, since afraid and dutiful of Allah resulted in straightness, honesty and righteousness, because the absolute brought back to Allah. So all behaviors of man are controlled included that related to money, however, in spite of the fact that private ownership is allowed in Islam, but also another absolute fact from the point view of Islam, it is that man is not free to do what he want by his private ownership, since there are permitted and prohibited financial practices mentioned in Quran.

2. Believe in the latest day for the purposes off accountability, and whosoever does good equal to the weight of atom shall see it, and whosoever does evil equal to the weight of atom shall see it, we should imagine this day and what is going to take place in. As it mentioned in Quarn, the time period of this day equal to 50000 years, as Allah the highest says: "To Him the angels and the Spirit (Gabriel) ascend in a day, the measure of which is fifty thousand years"(Quran, 70, 4), if we also consider that the day according to Quran equal to 1000 years as Allah the highest says: "They ask you to hasten the punishment. Allah will not break His promise. Each day with your Lord is like a thousand years in your reckoning"(Quran, 22,47), so the period of latest day in our reckoning if we consider the Hijri year as follow:

$$
\begin{gathered}
=(50000 * 355 * 1000=17750000000 \text { days } \\
\text { In hours }=17750000000 * 24=426000000000 \text { hours } \\
\text { In minutes }=426000000000 * 60=25560000000000 \text { minuties } \\
\text { In seconds }=25560000000000 * 60=1533600000000000 \text { seconds }
\end{gathered}
$$


The question why the researcher mention these equations? the answer simply: the latest day is a horrible day, two long day, and no second out of the above 1.533 quintillion seconds is absurdity or causeless, since every second will be busy, but the people disparage the orders of Allah and dare to do bad things like sinfully consuming public money without the right to do so without paying attention to Allah promise to absolute returning back to his highest in the latest day, its long, events, fire, hell, and all related varieties of torments are sufficient to avoid all types of bad practices, and people should consider his book that he will read it by himself at that day is very accurate and does not leave any thing he did in the first life but recorded, and there will be accountability and recompense, on the very smallest level, for example those who steal \$20 of public money, in cents they will be 2000 cents, every cent belong a right to someone if there is no theft, in the latest day those people will take their rights and those polytheists and wrong doers will pay these rights, not in cash, nor in properties, but through their good things, or incurred bad things since those are the only two measurement bases,

3. Values, ethics, and morals requirements that all related persons in budgets and public finance must characterized by, these requirements simply are the Islamic morals, such as: faith, fair, justice, truth, trustworthy, workaholic, well doing, loyalty, and the like, these are the qualitative controls to human behaviors, other than the current qualitative factors in accounting such as: qualitative characteristics of financial information, international auditing standards, ethical requirements and so on, that latest in my opinion are not sufficient to steer and guide human behaviors, and that what in reality happened through bankruptcies, quick and huge fortune, redistribution income and wealth to the interest of rich people....etc, so there is a mass need to religion values and morals to control human practices.

4. Joint efforts: goals can not be achieved except by joint efforts, the verses 47-49 includes seven main practices, that are: sow, reap, leave, eat, laid, guard, and press, the main idea to be raised is the importance to work within associated harmonious group other than work lonely, that indicates the responsibility of budgeting process is not laid on preparers, but also on all related parties, like: legislators, government, judiciary, executers, head of country, ....etc, the seven main practices lead to the following results:

a. Preservation the revenues for the purposes of sustainable development and investment according to saying of Allah the highest: "sow".

b. The integrity of revenue collection according to saying of Allah the highest: "reap".

c. Maintaining the public funds by avoidance it from theft, rubbery, and stealthiness, according to saying of Allah the highest: "leave".

d. Controlling the expenditures without wasting resources, according to say of Allah the highest: "eat".

e. Contributing in covering the expenditures by local revenues with maintaining surplus especially in crises, according to saying of Allah the highest: "laid".

f. Maintaining public surpluses from all bad practices, according to saying of Allah the highest: "guard", and

g. Continuous work and do the best efforts, according to saying of Allah the highest: "press".

5. Effective financial planning: budgeting process assumed to be for different purposes in term of time, three main types of budgeting(planning) as follow:

a. Long term financial planning: this type of planning attribute to the vision that country look forward to achieve, it takes long period of time to do so, that expressed in interpretation of the dream by fifteen years ( seven consecutive years, seven hard years, and the year of press), governments should consider this type of planning to achieve goals that are not easy to do so, like settlement of public dept, achieving advanced rank in development, self independence, treatment with crises, and so on.

b. Med term planning: this type of planning represents the broken down of long term planning, according to progression to achieve vision, it divides long period of time to interim periods, that expressed in interpretation of the dream by two periods, every period equal to seven years, to every seven years has its own requirements, the first seven yeasrs are the consecutive years, its basic requirements are pressing expenditures and maintaining the large surplus, this is obvious in Allah the highest saying: "For seven consecutive years, you shall sow as usual and that (the 
harvest) which you reap you shall leave it in the ears, (all) except a little of it which you may eat(47), while the second seven years are the hard years, its basic requirements are conservative expenditures and maintaining minimum limit of surplus, this is obvious in Allay the highest saying: "Then will come after that, seven hard (years), which will devour what you have laid by in advance for them, (all)except a little of that which you have guarded (stored)(48).

c. Short term planning: this type of planning expressed by yearly basis planning, since the vision and main objective can not be achieved except by action plans, this concentrate on the importance of yearly basis of budgeting, since progress to achieve vision and objectives can be identified except by determining the annual goals and the procedures adopted to achieve these goals, also the priorities of expenditures must be given to maintain human being existence, this is obvious in Allay the highest saying: " eat".

6. Goals and items of budget: It assumed that the main objective of governments should be achieving the welfare of its nations especially food security according to Allah the highest saying: "eat", the main source of feed is agriculture, so UNDP HR report assures the main strategy that can be adopted by governments must focus on increase production from agricultural corps, and require from governments serious change in nature of governmental expenditures by centralizing on investing expenditures especially the agricultural one (UNDP, 2011).

however the budget should meet the basic needs and how to achieve it by the limited resources, the accompanied idea is that the governments are agents work on behalf of its nations to manage the public funds, that idea is very clear during the Amawi khalifa Omar Ibn Abdel Aziz when he sent some one all over the Islamic Emperor that days, to cry whosoever not have a home, the government will construct him a home, and whosoever not married, the government will give him the opportunity to marry, and whosoever have a dept and can not pay it the government will settle his dept, this is the completed and maximum welfare could be achieved during all ages.

Question can be raised here: can current governments do the same thing that khalif Omar Ibn Abdel Aziz did? The answer in my opinion: of course yes, but if the governors have the same degree of believe in Allah and the latest day, ethics, morals of Omar Ibn Abdel Aziz, because no one can deny that resources now a days are multi thousands if not millions of resources of Omar's days, but the problem is in the worst distribution of income and wealth between members of one nation.

7. Applying continuous budget concept: Expenditure will not be definitely spent one time a year, but it will spent on daily basis, and control of resources and expenditures must not be absented for a moment, because it is very easy and quickly to waste resources, because of that continuous budget concept assumed that at any point of time, budget must consider the estimates of revenues and expenditures to the next twelve months, since any deficiencies in revenues collection and expenditures spending during the year will affect the budget and welfare of nations, there is a mass need to apply continuous budget concept to effective control system to be committed to the budget.

\section{Proposed Approach for Budgeting}

The proposed approach for budgeting derived from verses 47-49 of Yousif Soura, Allah the highest says: [(Yusuf(Joseph) said:"For seven consecutive years, you shall sow as usual and that (the harvest) which you reap you shall leave it in the ears, (all) except a little of it which you may eat(47) "Then will come after that, seven hard (years), which will devour what you have laid by in advance for them, (all)except a little of that which you have guarded (stored)(48), "Then thereafter will come a year in which people will have abundant rain and in which they will press (wine and oil"(49)].

Those verses relate to the interpretation of the dream of the king that days by prophet Yousif peace of Allah upon him, the dream as Allah the highest says:[And the king(of Egypt) said: "Verily, I saw (in the dream) seven cows, whom seven lean ones were devouring, and seven green ears of corn, and (seven) others dry, $\mathrm{O}$ notables! Explain to me my dream, if it be that you can interpret dreams"].

The proposed approach consist of the following ordinal steps : 


\section{First Step: Revenue Forecasting}

This is the starting point for budgeting, other than the current situation in budgeting that start with estimation of expenditures, which considered as main determinant of size of budget, Allah the highest point to this main step in Quran in verse(Aya) 47 of Yusuf Surah, Allah the highest says:" :"For seven consecutive years, you shall sow as usual and that (the harvest) which you reap you shall leave it in the ears, (all) except a little of it which you may eat(47), the harvested product represents the revenue that will be used for expensing, that means the core of budget is the forecasting of revenues or sources of fund, the following rules can be used as guidelines for revenue forecasting:

1. Preparing forecasts for the items of revenues according to scientific basics, considering all the objective or systematic and subjective or discretionary that may influence revenues forecasting process.

2. Benefiting from the historical estimates to the last seven years by determining the amount of item according to its chronological estimates.

3. Adoption of trend analysis to recognize the trend of a specific item: systematic or unsystematic, ascending or descending, that means recognize relationships between estimate during specific years.

4. Estimating the initial amount of revenue item with consideration to expected discretionary factors such as crises, inefficiency in performance, inflation rate, international financial policies, ... etc.

5. Re-estimation of revenue item till the date on monthly basis, using actual collection, and establish new re-estimated amount for total and residual months according to the following equation:

Re-estimated total $=$

$\{($ actual collection/actual period in months $\} *$ residual period in months $)+$ actual collection $\}$

Accordingly, the revenue item amount can be re-estimated according to the following equation:

Re-estimated amount of revenue item for the residual period $=$

$$
=\text { Re-estimated total } *(\text { residual period in months/12) }
$$

\section{Second Step: Estimation of Expenditures}

Estimation of Expenditures size must be in light of forecasted revenues, that means estimated expenditures must less than estimated revenues to maintain surplus, and on all situations, expenditures must not reach ever to $100 \%$ of revenues.

Allah the highest point to this main step in Quran in verse(Aya) 48 of Yusuf Surah, Allah the highest says:"Then will come after that, seven hard (years), which will devour what you have laid by in advance for them, (all)except a little of that which you have guarded (stored)(48).

The idea mentioned in verse above correspond the usual behavior of people relates to their expensing nature, to make their expenses part of their revenues even the preparer of budgets themselves, it is suitable here to mention an old saying :" as presume of your counterpane, overreach your legs", so adapt yourself when you sleep according to your counterpane in order to cover all of your body, also other saying can be bear to mind, it is: " those who have not money, not necessary to spend", that means person is not obliged to spend while he has no money.

The following rules can be used as guidelines for estimation of expenditures: 


\section{Estimation of Recurring Operational Expenditures}

1. Preparing estimation of such expenditures according to scientific bases considering all factors whether objective or systematic and subjective or discretionary that may influence estimating expenditures process.

2. Benefiting from the historical estimates to the last seven years by determining the amount of item according to its chronological estimates.

3. Adoption of trend analysis to recognize the trend of a specific item: systematic or unsystematic, ascending or descending, that means recognize relationships between estimate during specific years.

4. Estimating the initial amount of item with consideration to expected discretionary such as crises, inefficiency in performance, inflation rate, international financial policies, ... etc.

5. Re-estimation of item till the date on monthly basis, using actual expenditures, and establish new re-estimated amount for total and residual months according to the following equation:

Re-estimated total $=$

$\{($ actual expenditures/actual period in months $\}$ *residual period in months)+actual expenditures $\}$

Accordingly, the amount of expenditure item can be re-estimated according to the following equation:

Re-estimated item amount for the residual period $=$ $=$ Re-estimated total $*($ residual period in months $/ 12)$

\section{Estimation of Irrecurring Non-Operational Expenditures}

1. Evaluation of expenditures till to date, and studying of its visibility and necessity by applying of Zero-Based Budgeting(ZBB) basics.

2. Analyzing capital budget according to specific rate of return expected to be achieved from these expenditures, and making mind about continuation of expenditure in development according to the actual return, if there is no return to such expenditures such as infrastructure, its importance and costs to completion must be evaluated, also alternatives when deviations take place.

\section{Restructuring of Expenditures}

Not all expenditures are at the same level of importance to societies, since some of them can be reduced to minimum limits because it there are useless and no expected benefits anticipated, governments must focus mostly on basic expenditures that maintain the life of people, so restructuring to entire expenditures need to be adopted, and determine the priorities of expenditures.

\section{Third Step: Finance through Surplus}

The saved surplus that was constituted because expenditures less than revenues can be used to finance expenditures in cases of expecting revenue shortage in comparison to expenditures,

Allah the highest point to this main step in Quran in verse(Aya) 48 of Yusuf Surah, Allah the highest says: "Then will come after that, seven hard (years), which will devour what you have laid by in advance for them, (all)except a little of that which you have guarded (stored)(48).that means accumulative surplus achieved in two stages:

First Stage: The expenditures in case of revenues surplus (in the first seven years)must be a percentage of revenues according to the saying of Allah the highest:" (all) except a little of it which you may eat(47)", this type of surplus can be called the highest limit of surplus. 
Second Stage: The expenditures in case of revenues shortage (in the second seven years)must not absorb all of surplus saved, once again surplus must be maintained conservatively after necessary expenditures, according to the saying of Allah the highest:" (all)except a little of that which you have guarded (stored)" this type of surplus can be called the lowest limit of surplus.

Currently, it was noticed that preparing budgets on the contrary of the mentioned steps as follow:

Firstly: Estimating of expenditures that determine the size of budget.

Secondly: Estimating revenues that will be used to finance the expenditures, if there is a shortage in revenues, many financial policies adopted in order to cover the deficit or part of it, these policies such as finance through imposing new taxes or fees. and if the deficit remains, it financed by borrowing from internal or external institutions or aids and the like.

But the important question may be raised here: why the deficit in budgets? The answer is not difficult, since there are many reasons behind the deficits in budgets, researcher may mention the important reasons as follow:

1. Overstatement of expenditures with the less ability to cover it through the local revenues, in my opinion this behavior on the contrary of behaviors of person and people, since both of them tend in nature to save, and spend money according to his income, but the behaviors of most governments tend to waste resources, consume savings in all ways, for example at the end of the year, governmental departments empty the balances of funds in its budgets by transferring the funds from items to other items, the important issue for the department not to leave funds because the will be not posted for the next year.

2. Also, most of the countries that their budgets suffered from deficits have a huge military expenditure, because of wars, inessential arming, revolutions, and the like.

3. in addition to that, there is no effective accountability relate to public finance and funds to ask governments by the parliaments and nations about wasting resources, as a result, many bad behaviors spread through like theft, rubbery, corruption, that lead to more expenditures without any benefits to the societies.

4. Some times, there are a big pressures on governments to borrow and accept aids, because such received funds attributable to hard terms and conditions like high cost of borrowing, fields of spending the borrowed funds, ruled over financial and monetary policies, .... Etc. .

Other question may be raised: can governments prepare budgets without deficits?

In my opinion yes, if the governments press its expenditures, activate an accountability system especially by the fourth authority, eradication of sinks of corruption, wastefulness, extravagance and profusion of resources, adoption of investing expenditures, control of expenditures, establishment of integrity and transparency code, redirecting and restructuring of governmental expenditures, reduce the military expenditures, tenure greatest and developed countries its ethical responsibilities that discourage the inessential expenditures and maintaining the sustainability development, controlling of the imports of technology particularly military, security, and spy one, controlling of the high authority expenditures, harmonization and convergence between public expenditures and level of revenues, avoiding of luxurious expenditures, freezing the showy expenditures, best choosing of public employees especially the decision makers and planners, focus on honest judiciary, appointment the suitable person in the suitable position, ...etc.

The third and last question is: what are the main categoreis of expenditures that governments must focus on? The answer must consider the expenditures that generate maximum benefits to the society, thus, the best field to invest in expenditures is agriculture for many reasons, such as: 
1. Agriculture is the main provider of food to human being, since the main goal of governments should be maintain the life of its people, that relate to maintain there existence, as it constitute the base of five Necessities hierarchy in Islam as it shown in the following form:

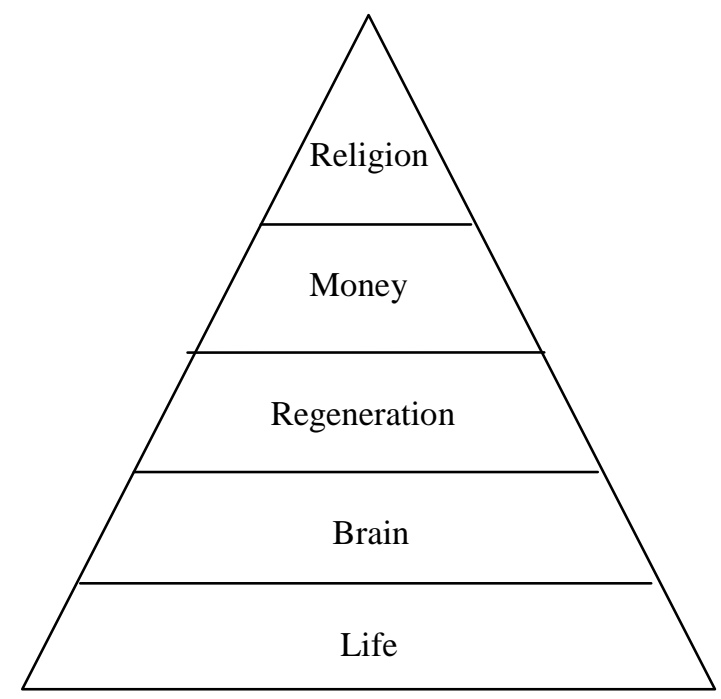

Form (1): Five necessities

2. Agricultural corps that will be grown should be planned and not grown randomly, according to interest of the society, for example the importance of wheat to the society not as the importance of melon.

3. Also the agriculture save the food of cattle through its remnants, cattle constitute a food of human being also.

4. Researcher look to agriculture that all available solutions to crises focus on it, if we have a look to most poorness countries are agricultural and watery, but because of absence of targeted plans to support agriculture in those countries, there is a minimum contribution to agriculture in Gross Domestic Production(GDP).

5. Agriculture considered the less costly industry, since the land necessary to grow corps is a gift of Allah, also, the stages of growing are costless because it is managed by Allah also, it differs from other field of investments.

\section{Conclusion}

But the budgets approaches used by governments are inconvenient since most of them suffered from deficits, that because way of preparation of it, since its centralization on expenditures as it represent the starting point of preparing budgets, and after that, governments look for sources in order to finance these expenditures, whether there are sufficient resources or incases on deficits look for extra sources by imposing new taxes and fees, or by borrowing from internal or external institutions, which burden the people.

Researcher discuss in details an Islamic idea depends on dream of an old king and interpretation of this dream by prophet Yusuf, the story mentioned in Quarn, and how to benefit from the idea, in simple words that idea of preparing budgets on the contrary of what take place in reality nowadays as it mentioned above, the starting point focus on revenues not expenditures, and estimation of expenditures depends on revenues with keeping expenditures less than revenues to maintain surplus. 


\section{References}

Al-Bukhari, Mohammed Ibn Ismael, Bukhari Hadith, Beirut, Lebanon, Dar Ibn Khatheer.

Holly Quran .

Jaarat, Khaled Jamal, Strategic Governmental financial planning, Dar Al-safa for publication and distribution, Amman, Second edition, 2017.

Moslem, , Mohammed Ibn Ismael, Moslem Hadith, Beirut, Lebanon, Dar Ibn Khatheer.

The legislation guarding the five necessities, Hkam A. Zummo Al-Aqaily and Dr.Abd Al-Kareem Ziddan, 2009,Islamic Propagation Office in Rabwa, Riyadh, Suadia Arabia.

UNDP, Human development report 2011Managerial natural resources for human development developing the non-oil economy to achieve the MDG, 2011.

UNDP, Human development report 2016 Human development for every one, 2016.

UNDP, Sustainability of Public finances - A key to overcoming the crisis , 2012. 